УДК: $74+76 / 766$

Вероніка Іванівна Зайцева,

кандидат мистецтвознавства,

Київський університет імені Бориса Грінченка,

Київ, Україна,

e-mail: nika.zaytseva@gmail.com,

ORCID: 0000-0003-1160-1760

\title{
ІЛЮСТРУВАННЯ ТВОРІВ ІВАНА КОТЛЯРЕВСЬКОГО СУЧАСНИМИ УКРАЇНСЬКИМИ ХУДОЖНИКАМИ-ГРАФІКАМИ
}

Анотація. Особливе місце в українській графіці завжди посідала книжкова графіка. Сучасний процес національного відродження актуалізує дослідження мистецької спадщини українських графіків, які оформлювали твори класиків української літератури. Зокрема актуальним у наш час $\epsilon$ дослідження ілюстрування творів Івана Котляревського та характеристика специфіки стилістичних прийомів, засобів художньої виразності видатних українських майстрів книжкової графіки у сучасному художньому трактуванні його літературних образів. Методологія дослідження полягає в застосуванні загальнонаукових методів (аналізу та синтезу, індукції та дедукції, єдності історичного і логічного) та мистецтвознавчих методів (компаративний, типологічний, описовий). Досліджуючи ілюстрації до творів українських літературних класиків, зокрема I. Котляревського, можна зазначити, що в цих роботах засобами художньої виразності відображені водночас історія вітчизняної графіки та історія культурно-історичного поступу України. Малодослідженим матеріалом є приклади художнього оформлення творів І. Котляревського за весь період Незалежності України. Тому надзвичайно плідним об'єктом дослідження $є$ роботи майстрів книжкової графіки в сучасній художній трактовці літературних образів Івана Котляревського. 
Аналіз досвіду нового осмислення творів Котляревського в незалежній Україні здійснено на основі вивчення робіт сучасних українських художників-ілюстраторів Івана Будза, Сергія Донця, Олени Зеркалій, Людмили Кириленко, Андрія Печенізького, Оксани Тернавської, Віктора Яременка. Літературна спадщина Івана Котляревського й досі хвилює творчу уяву художників, чиї роботи переконливо свідчать про невпинні пошуки відповідних образотворчих втілень, що вводять у сучасний вимір літературне слово поета.

Ключові слова: культура, книга, мистецтво, ілюстрація, художники, книжкова графіка, українська незалежність

Вступ. Процеси демократизації та національного відродження неабияк актуалізують потребу в дослідженні творчості українських майстрів книжкової графіки. У цьому сенсі важливо простежити еволюцію художньої інтерпретації літературних образів Івана Котляревського у сучасній художній трактовці. що $є$ предметом дослідження та розкриває зміст і джерело відповідних мистецьких тенденцій у культурноісторичному просторі України зазначеного періоду.

Аналіз останніх досліджень і публікацій. Здобуткам вітчизняних майстрів книжкової ілюстрації присвячено чимало мистецтвознавчих робіт, зокрема, таких знаних науковців як О. Авраменко, Ю. Белічко, П. Білецький, Б. Валуєнко, І. Верба, Л. Владич, М. Гордійчук, М. Криволапов, О. Лагутенко, О. Ламонова, Д. Малаков, О. Петрова, О. Роготченко, О. Сидоров, Л. Турчак, О. Федорук, А. Шпаков, Р. Яців та ін., в яких розглядаються різні школи, напрями, особливості творчого методу.

Серед робіт, присвячених українській книжковій графіці, особливе місце посідають праці Леоніда Владича. Він чи не першим із мистецтвознавців помітив, зрозумів графіків нової генерації саме як художників книги і сміливих реформаторів книжкового мистецтва. Так, у книзі Л. Владича «Мовою графіки» 
[3] проаналізовано, як змінювались художні смаки та стилі у процесі оформлення літературних творів.

Відомий мистецтвознавець Анатолій Шпаков у своїй праці «Художник і книга» [12] досліджує шляхи становлення і розвитку української книжкової графіки, розкриває творчий доробок українських художників-ілюстраторів радянського періоду. Автор зазначає, що «саме у виборі найважливішого 3 точки зору ілюстратора й виявляється його творча індивідуальність та його тенденційність. Це пояснюе й різнохарактерність трактування певних класичних творів в ілюстраціях різних художників» [12].

У монографії відомого критика та мистецтвознавця Михайла Криволапова детально розглядаються ілюстрації Анатолія Базилевича до «Енеїди» [6]. Ця монографія й досі залишається однією з фундаментальних праць про художника, де автор зазначає: «Базилевич підійшов до «Енеїди» I. Котляревського не як до припалої порохом старовини, а як до живого, співзвучного почуттям і думкам наших сучасників» [6].

Образотворча мова була чутливою до мистецьких шукань, у творах помітні впливи різних художніх напрямів футуризму, неопримітивізму, експресіонізму, кубізму, конструктивізму, хоча визначальними залишалися традиційні мотиви, зазначає Ольга Лагутенко в книзі «Українська графіка першої третини XX століття» [8].

Серед останніх загальних праць найгрунтовніше українська графіка представлена у п'ятому томі «Історії українського мистецтва» (2006 р.) [4]. Так, у розділі «Мистецтво другої половини 1950-х - 1980-х років» висвітлені основні етапи розвитку та здобутки українського образотворчого мистецтва. Зокрема, у публікації-есе «Після соцреалізму» Олесі Авраменко окреслено загальний стан українського мистецтва 31992 р. періоду української незалежності [1]. Докладніше книжкова графіка II пол. XX ст. досліджена у статті «Книжкова графіка» Оксани Ламонової [10]. 
Втім, дослідження творчого доробку українських майстрів книжкової графіки за часів Незалежності України все ж не можна назвати вичерпаним.

Мета статті полягає у дослідженні аспектів образновізуальної мови ілюстрування творів Івана Котляревського українськими художниками-графіками у друкованих виданнях доби української незалежності в контексті відображення українського культурного простору та специфіки стилістичних прийомів, засобів художньої виразності у сучасному художньому трактуванні літературних образів Івана Котляревського.

Виклад основного матеріалу. Особливе місце в українській книжковій графіці завжди мала мистецька спадщина ілюстрування творів класиків української літератури. У сучасному мистецтвознавстві досі бракує системного дослідження розвитку та особливостей сучасного вітчизняного мистецтва книги, тому $є$ необхідність грунтовного аналізу прикладів ілюстрування друкованих видань творів I. Котляревського за весь період незалежної України.

Першим на початку 1990-х рр. поему «Енеїда» Івана Котляревського проілюстрував художник-графік, мультиплікатор Іван Федорович Будз. По закінченню факультету графіки Львівського поліграфічного інституту iм. I. Федорова художник працював на кіностудії «Київнаукфільм», в об’єднанні художньої мультиплікації. Водночас Іван Будз плідно працює в галузі мистецтва книги. Співпрацюючи з різними видавництвами, він створив ілюстрації до творів іноземних та українських письменників i, зокрема, до «Енеїди» I. Котляревського.

Видання поеми «Енеїда» 3 ілюстраціями Івана Будза надруковано у видавництві «Дніпро», 1995 р. та перевидано у видавництві «Книга», 2008 р. Це надзвичайно вдале подарункове видання - великий формат, тверда палітурка, сатиричні повноколірні сторінкові малюнки і небагато тексту, 
що їх супроводжує. Макет видання задуманий художником у вигляді сучасних коміксів - яскравий, динамічний, привабливий. I хоча 3 написання твору минуло 250 років, видання, проілюстроване Іваном Будзем, виглядає сучасним i новаторським, а коміксна інтерпретація «Енеїди» сприяє залученню молоді до прочитання українського класичного літературного твору (рис. 1).

Цікавими $є$ ілюстрації до поеми «Енеїда» харківських художниць Людмили Кириленко та Олени Зеркалій, які в 2012 р. були відмічені дипломами лауреатів книжкової премії «Левеня» (м. Львів) у номінації «Нові видання української
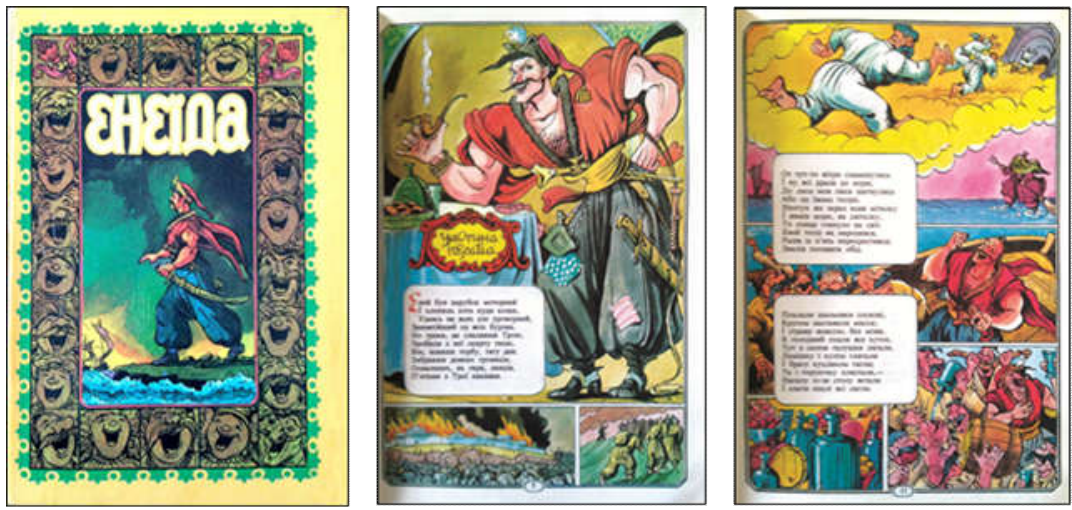

Рис.1. Будз І. Обкладинка та ілюстрачії до поеми «Енеїда» I. Котляревського. 1995 р.

класики, суттєво змінені порівняно 3 наявним». Книга була видана у 2010 р. харківським видавництвом «Ранок» і одразу привернула до себе увагу читачів яскравою кольоровою палітуркою та багатофігурними сторінковими ілюстраціями (рис. 2).

Також у 2010 р. виходить ще одне перевидання «Енеїди». Власником авторських прав на це видання $є$ книжковий «Клуб сімейного дозвілля». Ілюструє поему харківський художник- 
графік Андрій Миколайович Печенізький. По закінченню Харківського художньо-промислового інституту він працює у галузі книжкової графіки. В графічному оформленні митця вийшло близько 400 видань. Він став автором ряду обкладинок та ілюстрацій до кількох збірників фантастики.

Ілюстрації Андрія Печенізького до «Енеїди» вирізняються яскравим індивідуальним художнім почерком, своєрідною пластикою та прагненням емоційності художнього виразу. Графічні роботи, виконані чорною тушшю та пером, автор стилізує під ліногравюру.
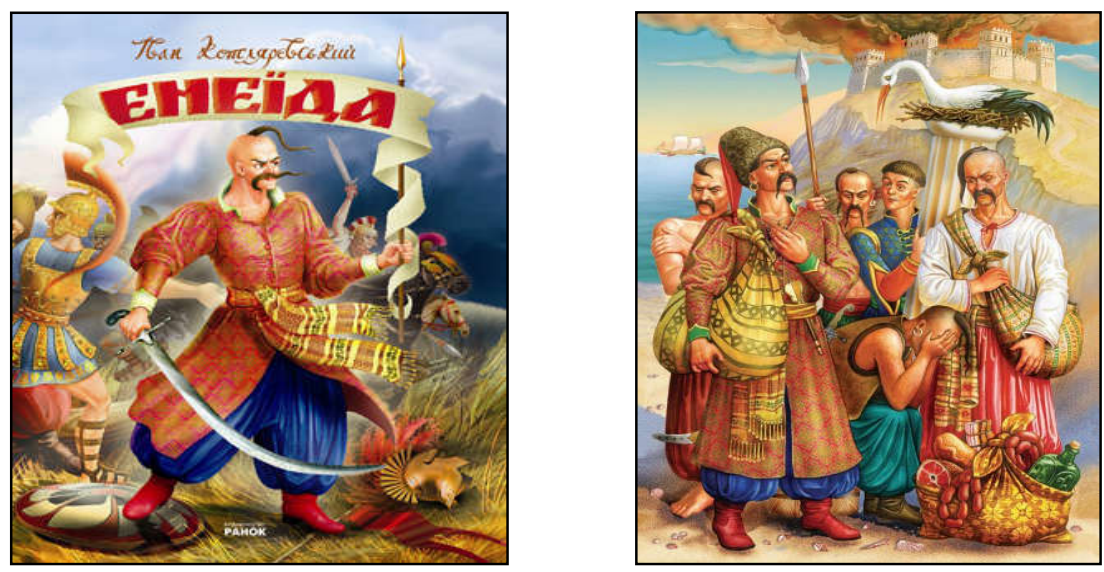

Рис. 2. Кириленко Л., Зеркалій О. Обкладинка та ілюстрація до поеми «Енеїда» I. Котляревського. 2010 р.

Художником було виконано вісім сторінкових малюнків до поеми, в яких вражає динаміка, чіткість і переконливість малюнка, різноплановість та змістовність багатофігурних композицій. Друкований примірник цього видання зберігається в Музеї книги і друкарства України. (Рис. 3). 

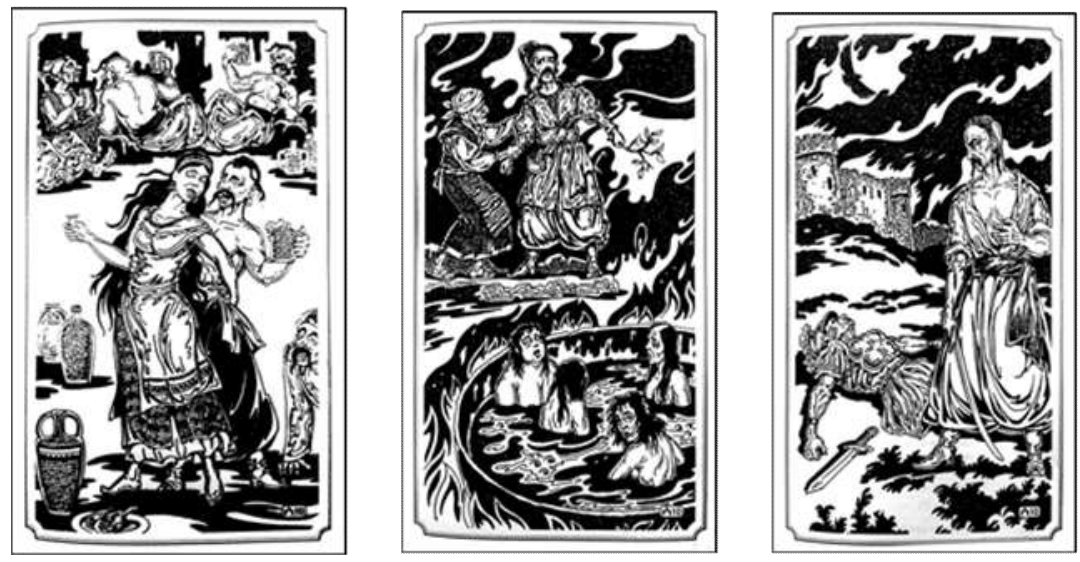

Рис. 3. Печенізький А. Ілюстрації до поеми «Енеїда» I. Котляревського. 2010 р.

Наступне сучасне перевидання поеми «Енеїда» I. Котляревського, що вийшло друком у 2010 р. у київському приватному видавництві «Корбуш», особливо заслуговує на увагу. Художнє оформлення до цього видання створила київська художниця Оксана Іванівна Тернавська. Закінчивши Київський художньо-промисловий технікум («художне оформлення»), навчалася у Київському поліграфічному інституті («книжкова графіка»). Художниця займалась розробкою логотипів, фірмових знаків, макетів обкладинок книжок, їх ілюструванням та макетуванням, розробкою листівок, марок, конвертів, художніх та рекламних плакатів. Але основним напрямком роботи стало оформлення та ілюстрування книжок у співпраці із видавництвами «Махаон-Україна», «Літера», «Аконіт», «АСК», «Теза», «Марка України». Вона є членом Національної спілки художників України.

Якщо літературознавці час від часу розглядали поему «Енеїда» в контексті барокового мистецтва, то для ілюстраторів 
ця риса тривалий час не викликала особливого зацікавлення. Втілити у зображенні барокові мотиви вирішила Оксана Тернавська. Нове видання «Енеїди» дійсно вражає, адже книгу готували 3 роки. Майстерно вимальовані пензлем художниці персонажі вдало розмістились у розкішних декораціях українського бароко.

Відомо, що мистецтво книжкової ілюстрації в деяких аспектах наближене до мистецтва театру, і художник книги - це головний режисер дії. Так, у цій книзі О. Тернавська стала i режисером, i костюмером, i декоратором. Завдяки цьому створено неповторний світ, книга виглядає як чарівна вистава, персонажі якої прийшли до нас із глибин віків. Усе це змушує читача вкотре повертатися до книги - до тексту та ілюстрацій. У макеті органічно поєднуються сторінкові багатофігурні малюнки, декоративні барокові заставки та вишукані кінцівки. «Поема Котляревського стала для художниці поштовхом для створення власного культурного універсуму, насиченого знаками, історичними та міфологічними алюзіями, іронічними співпадіннями та промовистими деталями. Ілюстрації перестають бути тільки «доповненням до тексту, вони створюють власне мистецьке поле, стаючи самодостатнім артефактом... Важливо, як художник відчула внутрішню енергію тексту і часу, як виплеснула на папір оту «натуру, що іде», - українську барокову культуру, останні спалахи якої ще застав I. Котляревський» - пише про це видання мистецтвознавець, доктор філософських наук Н. Ю. Кривда [5, c. 8-12].

Хоча оцінювання такої трактовки поеми є неоднозначним. Наприклад, наявні дещо зайва реалістичність, деяка поверховість психологічних характеристик образів (рис. 4). 


\section{АРТ-платФОРМА. 2020. Вип. 2}
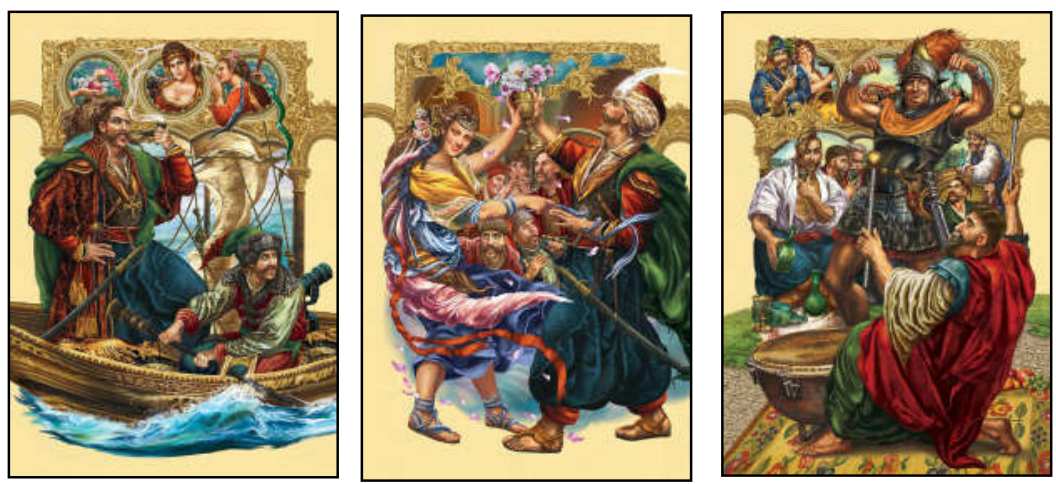

Рис. 4. Тернавська О. Ілюстрації до поеми «Енеїда»

I. Котляревського. 2010 p.

У 2011 р. в донецькому видавництві «Бао» була підготовлена до друку збірка творів І. Котляревського, до якої увійшли поема «Енеїда», опера «Наталка Полтавка» та український водевіль «Москаль-чарівник». Ілюстрації до цього видання виконав Сергій Михайлович Донець. Художнє оформлення до книги виглядає досить аскетично. Так, наприклад, чорно-білі рисунки тушшю виконані в саркастичному стилі і виглядають майже карикатурно.
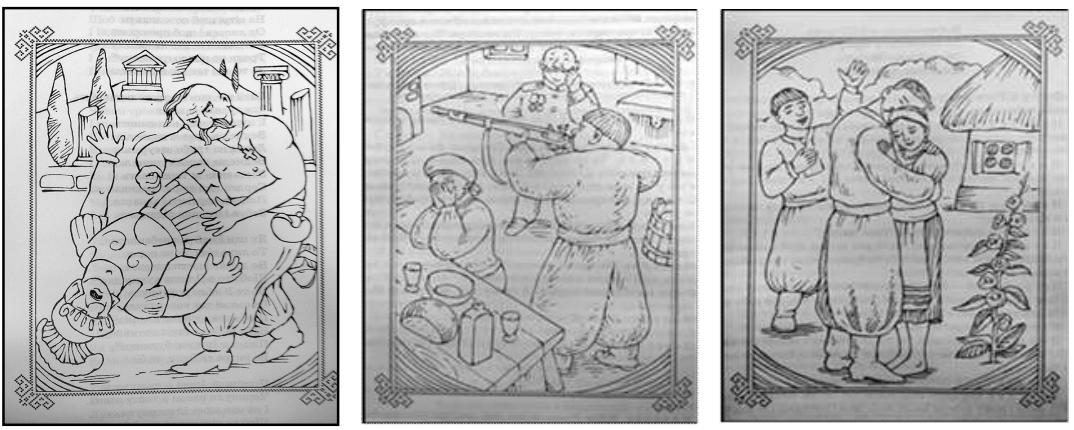

Рис. 5. Донеиь С. Ілюстраиії до творів «Енеїда», «Наталка Полтавка», «Москаль-чарівник» I. Котляревського. 2011 р. 
Композиції сторінкових ілюстрацій досить лаконічні та спрощені. Автор зображує персонажі даних цих дещо стримано (рис. 5).

Деякі 3 сучасних українських видавництв i досі недооцінюють українського читача. Страх не продати книгу нерідко заважає видавцю зважитися на цікаві ідеї. Саме 3 економічних міркувань, на жаль, іноді маємо випадки такого, дещо спрощеного художнього оформлення видань.

Та все ж за останні роки на українському книжковому ринку побільшало цікавих експериментів ілюстрування 3 застосуванням комп'ютерних графічних програм. Таким виданням поеми «Енеїда», яке заслуговує на нашу увагу, є книга в оформленні художника-ілюстратора i живописця Віктора Григоровича Єременка. Після закінчення Харківського художньо-промислового інституту, 1988 р., він стає членом Національної спілки художників України, дипломантом всесоюзних та міжнародних мистецьких виставок і конкурсів.

Для творчості Єременка характерний експеримент (використовує олівець, туш, пастель, вугілля, соус). Графічна мова його творів відзначається розмаїттям динамічних ліній, ретельним моделюванням форми, увагою до деталей. Окремі роботи художника зберігаються у музеях Білорусі, Казахстану, Канади, Німеччини, Польщі, Словаччини, США, України, Чехії, Франції.

На XXII Львівському міжнародному Форумі видавців, який відбувся 2015 р., серед представлених книг авторитетне журі обрало 20 кращих. До числа переможців Форуму увійшло подарункове видання поеми «Енеїда» Івана Котляревського, підготовлене до друку у харківському Видавничому домі «Школа». Розробником оформлення цього унікального видання та його виконавцем став Віктор Єременко. Роботі над цим творчим проектом художник присвятив 3 роки. Це подарункове видання «Енеїди» має унікальний, гарно продуманий дизайн макету (футляр, палітурка з матового покриття «під шкіру», 
тиснення, поєднане 3 золотими написами). Вишукані ілюстровані розвороти виконані за допомогою комп'ютерної графіки. Художник засобами гротеску створив яскраві, емоційно насичені, життєлюбні образи, що завжди були притаманні українському народу (рис. 6).
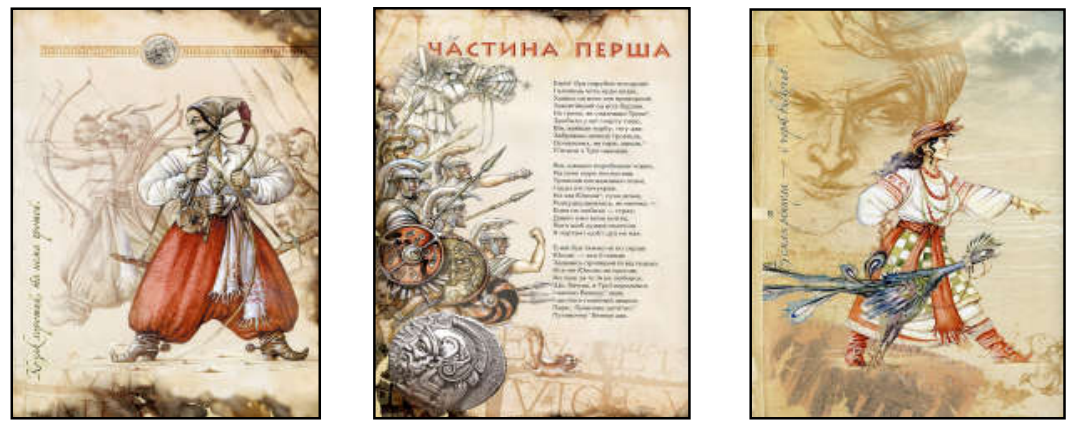

Рис. 6. Сременко В. Ілюстрації до поеми «Енеїда» I. Котляревського. 2015 p.

Висновки. Здійснений аналіз художньої інтерпретації образів Івана Котляревського доби Незалежності України засвідчив, що сучасні українські художники в нових соціокультурних умовах були «звільнені» від політичної цензури, зокрема в мистецтві оформлення книги. Отже, досліджуючи роботи вищезазначених митців у жанрі книжкової ілюстрації до творів Івана Котляревського, ми зазначаємо існування розмаїття стилістичних $\mathrm{i}$ художніх прийомів: основним напрямком у роботах стало комплексне макетування книг; синтетичність, декоративність, схильність до складної символіки в оформленні обкладинок та ілюстрацій; побільшало цікавих експериментів ілюстрування 3 застосуванням комп'ютерних графічних програм, що збагачують сучасну образно-візуальну мову, сприяючи вираженню творчої індивідуальності художників. Мовою фарб та образів сучасні українські художники передають відчуття духовного багатства, 
героїчного минулого України, вшанування народних традицій, про які так дбав I. Котляревський. Твори сучасних українських митців відзначаються глибоким переосмисленням художньої форми, в яких філософський підтекст домінує над відкритою сюжетно-інформаційною довідковістю. Це пояснює емоційну і смислову різнохарактерність ілюстрування творів I. Котляревського, а також має безпосередній вплив на популяризацію його літературної спадщини.

\section{Література}

1. Авраменко О. Після соцреалізму. Нова Генерація. 1992. C. 32-34.

2. Белічко Н. Книжкова графіка 50-70-х років XX століття. Рукописна та книжкова спадщина України. 2003. Вип. 8.

C. 126-141.

3. Владич Л. Мовою графіки. Київ: Мистецтво, 1967. 248 с.

4. Історія українського мистецтва: у 5 т. НАН України, ІМФЕ ім. М. Т. Рильського. Київ, 2007. Т. 5 : Мистецтво ХХ століття. $1048 \mathrm{c}$.

5. Кривда Н. До історії ілюстрування «Енеїди» Івана Котляревського. Вісник КНУТШ. 2013. № 112. С. 8-12.

6. Криволапов М. Анатолій Базилевич. Київ: Мистецтво, 1976. $96 \mathrm{c}$.

7. Криволапов М. Про мистецтво та художню критику ХХ століття. Київ: ІПСМ, 2006. 227 с.

8. Лагутенко О. Українська графіка першої третини ХХ століття. Київ: Грані-Т, 2003. 128 с.

9. Лагутенко О. Українська графіка XX століття: монографія. Київ: Грані-Т, 2011. 184 с.: іл.

10. Ламонова О. Шляхи української графіки II-ї половини XX століття. «Мистецька мапа України. Київ». Проект Музею сучасного мистецтва України. Каталог. Київ, 2015. С. 246-247. 
11. Популярная художественная энциклопедия. Под ред. В. М. Полевого. Москва: Советская энциклопедия, 1986. $476 \mathrm{c}$.

12. Шпаков А. Художник і книга. Киїі: Мистецтво, 1973. 256 с.

\title{
Вероника Ивановна Зайцева,
} кандидат искусствоведения, Киевский университет имени Бориса Гринченко,

Киев, Украина, e-mail: nika.zaytseva@gmail.com, ORCID: 0000-0003-1160-1760

\section{ИЛЛЮСТРИРОВАНИЕ ПРОИЗВЕДЕНИЙ ИВАНА КОТЛЯРЕВСКОГО СОВРЕМЕННЫМИ УКРАИНСКИМИ ХУДОЖНИКАМИ -ГРАФИКАМИ}

\begin{abstract}
Аннотация. Особое место в украинской графике всегда занимала книжная графика. Современный процесс национального возрождения актуализирует исследования художественного наследия украинских графиков, которые оформляли произведения классиков украинской литературы. В частности актуальным в наше время является исследование творческого наследия иллюстрирования произведений Ивана Котляревского и характеристика специфики стилистических приемов, средств художественной выразительности выдающихся украинских мастеров книжной графики в современной художественной трактовке его литературных образов. Методология исследования заключается в применении общенаучных методов (анализа и синтеза, индукции и дедукции, единства исторического и логического) и искусствоведческих методов (компаративный, типологический, описательный). Исследуя иллюстрации к произведениям украинских литературных классиков, в частности И. Котляревского, можно
\end{abstract}


отметить, что в этих работах средствами художественной выразительности отразились одновременно история отечественной графики и история культурно-исторического развития Украины. Малоисследованным материалом являются примеры художественного оформления произведений И. Котляревского за весь период независимости Украины. Поэтому, чрезвычайно плодотворным объектом исследования являются работы мастеров книжной графики в современной художественной трактовке литературных образов Ивана Котляревского. Анализ опыта нового осмысления произведений Котляревского в независимой Украине осуществлено на основе изучения работ современных украинских художниковиллюстраторов Ивана Будза, Сергея Донца, Елены Зеркалий, Людмилы Кириленко, Андрея Печенежского, Оксаны Тернавской, Виктора Яременко. Литературное наследие Ивана Котляревского и сегодня волнует творческое воображение художников, чьи работы убедительно свидетельствуют о беспрестанных поисках новых изобразительных воплощений, которые вводят в современное измерение литературное слово поэта.

Ключевые слова: культура, книга, искусство, иллюстрация, художники, книжная графика, украинская независимость 


\author{
Veronika I. Zaitseva, \\ $\mathrm{PhD}$ in Arts, \\ Borys Grinchenko Kyiv University, \\ Kyiv, Ukraine, \\ e-mail: nika.zaytseva@gmail.com, \\ ORCID: 0000-0003-1160-1760
}

\title{
ILLUSTRATING OF THE WORKS BY IVAN KOTLYAREVSKY BY MODERN UKRAINIAN GRAPHIC ARTISTS
}

\begin{abstract}
Book graphics have always occupied a special place in Ukrainian graphics. The modern process of national revival actualizes the study of the artistic heritage of Ukrainian graphic artists, who designed the works of classics of Ukrainian literature. In particular, the study of the artistic heritage of illustrating the works of Ivan Kotlyarevsky and characterizing the specifics of stylistic devices, means of artistic expression of prominent Ukrainian masters of book graphics in the modern artistic interpretation of his literary images is relevant today. Research methodology is to apply scientific methods (analysis and synthesis, induction and deduction, unity of historical and logical) and methods of art (comparative, typological, descriptive). Exploring illustrations of the works of Ukrainian literary classics, including Kotlyarevskiy, we note that in these works means of artistic expression reflected both the domestic graphic story and history of the cultural and historical development of Ukraine. The little-researched material is an example of the artistic design of the works of I. Kotlyarevsky's for the entire period of Independence of Ukraine. Therefore, extremely fruitful object of study is the works of masters book graphic art in the modern interpretation of literary images of Ivan Kotlyarevsky. The analysis of the Kotlyarevsky's new thinking art works in independent Ukraine carried out based on the study of contemporary Ukrainian artists and illustrators Ivan Budz, Sergei Donets, Elena Zerkali, Lyudmila Kirilenko, Andrew
\end{abstract}


Pechenigy, Oksana Ternavska, Viktor Yaremenko. The literary heritage of Ivan Kotlyarevsky still excites the creative imagination of artists, whose works convincingly testify to the relentless search for appropriate visual incarnations that introduce the poet's literary word into the modern dimension.

Key words: culture, book, art, illustration, artists, book graphics, Ukrainian independence

\section{References}

1. Avramenko, O. (1992) Pislia sociarealismu. Nova Generacia [After Socialist Realism]. 32- 34. [in Ukrainian].

2. Belichko, N. (2003). Knishkova grafika 50-70h rokiv XX stolittia [Book graphics of the 50-70s of the XX century], 8, 126-141. Kyiv: [in Ukrainian].

3. Vladich, L. V. (1967). Movoyu grafiky [In the language of graphic arts]. Kyiv: Mystetstvo [in Ukrainian].

4. Istoria ukrainskogo mystectva: 5 t. [History of Ukrainian Art: 5] (2007). National Academy of Sciences of Ukraine, IMFe them. M. T. Rylsky, 5, 1048. Kyiv: [in Ukrainian].

5. Kryvda, N. (2013) Do istorii ilustryvannia "Eneidy" Ivana Kotliarevskogo [To the history of illustrating Ivan Kotlyarevsky's "Aeneida"]. Visnyk KNUTSH. 112, 8-12. Kyiv: [in Ukrainian]..

6. Krivolapov, M. O. (1976). Anatoli Bazilevich [Anatolii Bazilevich]. Kyiv: Mistetstvo [in Ukrainian].

7. Krivolapov, M. (2006). Pro mystetstvo ta hydoznu krytyku XX stolittia [About art and artistic criticism of the twentieth century]: Collection of scientific works, 227. Kyiv: [in Ukrainian].

8. Lagytenko, O. (2003). Ukrayins'ka grafika pershoi tretiny $\mathrm{XX}$ stolittia [Ukrainian graphics of the first third of the twentieth century]. Kyiv: Grani-T [in Ukrainian].

9. Lagytenko, O. (2011) Ukrayins'ka grafika XX stolittia [Ukrainian graphic arts of the XXth century]. Kyiv: Grani-T [in Ukrainian]. 
10. Lamonova, O. (2000), Shliahy ukrainskoi grafiky II-i poloviny XX stolittia. "Mystecka mapa Ukrainy. Kyiv" [Ways of Ukrainian graphic art of the second half of the twentieth century. Fine art] [in Ukrainian].

11. Populyarnaya khudozhestvennaya encyclopefiya [Popular artistic encyclopedia]. (1986). Ed. V. M. Poluevoi Moscow: Sovetskaia Encyklopedia [in Russian].

12. Shpakov, A. (1973) Hydoznik i kniga [Artist and book]. Kyiv: Mistetstvo [in Ukrainian]. 